IJLRES - International Journal on Language, Research and Education Studies

ISSN: 2580-6777 (p); 2580-6785 (e)

DOI: $10.30575 / 2017 /$ IJLRES-2018050802

Vol. 2, No. 2, 2018

Page: $169-175$

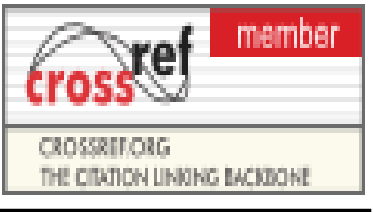

\title{
INVESTIGATION OF SITUATIONAL - PEDAGOGICAL FACTORS AFFECTING SPEAKING RELUCTANCE AMONG UNIVERSITY EFL STUDENTS
}

\author{
Abdolnoor Khaleghi \\ Faculty of Education, Malaya University, Kuala Lumpur, Malaysia \\ a.khaleghi.ling@gmail.com
}

\begin{abstract}
In second and foreign language acquisition, a number of factors appear to contribute to predisposing one learner to seek and another learner to avoid L2 communication. It is also believed that speaking as a means of oral participation in university EFL classrooms is an anxietyprovoking phenomenon. Some factors make students be reluctant to use L2 in speaking settings. It may be regarded as the most challenging concern that instructors are recently facing in EFL classes. Consequently, this study was conducted to investigate the underlying factors affecting speaking reluctance among university students and to suggest solutions to this problematic issue. Data were gathered through an informal 12-items Likert-scale questionnaire and a semistructured interview. The results indicated that several situational factors (instructors' behavior, class atmosphere and topic selection) and pedagogical factor (teaching style, instructor-student relationship, course materials, educational system and low English proficiency) cause students' speaking reluctance in academic EFL settings.
\end{abstract}

Keywords: Speaking, Reluctance, Pedagogical, Situational, Oral.

\section{INTRODUCTION}

Nowadays, in communicative language teaching approaches, one of the most significant role of Speaking as an important element in developing each language skill and conveying culture knowledge, is to serve as a vehicle for participating in class activities. In such communicative environments exposed to real language, they can develop more effective communication skills which are typical in traditional teaching methods like grammar translation and audio-lingual ones ${ }^{1}$. The most realistic opportunity teachers have to demonstrate is the practical use of second language to communicate. Tsou notes that of the four skills that make up language proficiency, oral participation is the most observable phenomenon in the classroom². Moreover, Ellis

\footnotetext{
${ }^{1}$ Schmitt. R. (2010). An introduction to applied linguistics. Hodder Education, An Hachette UK Company.

2 Tsou, W. (2005). Improving speaking skills through instruction in oral classroom participation. Foreign Language Annals, 38(1), 46-55.
} 
states that we learn language when we use it in a real situation ${ }^{3}$. Language acquisition and language use are complementary. As a result, use of language in communicative academic settings like EFL classrooms is a crucial factor. However, sometimes some students are not willing to use language in EFL oral courses. For years, this reluctance has been a challenging issue among University EFL students from the beginning to the advanced levels.

The act of being reluctant to participate or speak using the target language has always been considered as the main source of frustration, and failure for both instructors and students ${ }^{4}$. Asian students are frequently portrayed as reticent and passive in the English language classrooms with minimal or no contribution to the classroom discourse $^{5}$. This situation will become worse if it remains unresolved for a period of time. This is because students might either wrongly perceive that the behavior is acceptable, or it is a norm for a language classroom. This issue is undeniably important in the field of language pedagogy that it deserves to be delved into thoroughly and multiple reasons of EFL students' reluctance to participate orally in class have been identified in previous studies conducted on the Asian EFL settings.

Compared to studies conducted on affective factors affecting reluctance among EFL learner in oral classrooms, little studies have been done on situational and pedagogical and factors which may be the main causes of affective factors. However, it is not a simple question to answer, particularly when one takes into account the various relevant individual, social, linguistic, situational, and other factors that may prevent one from speaking up ${ }^{6}$.

Everyone in his life and education needs concentration and repose to do well their daily and working affairs. Sometimes there are obstacles which prevent us to act and behave actively and effectively. It is true about language learning and specifically

${ }^{3}$ Ellis, R. (2005). Principles of Instructed Language Learning. Volume 7, Asian EFL Journal. 209-224.

${ }^{4}$ Zhang, X, \& Head, K. (2010). Dealing with learner reticence in the speaking class. ELT Journal, 64(1), 1-9.

5 Hamouda, A. (2013). An exploration of causes of Saudi students' reluctance to participate in the English language classroom. International Journal of English Language Education, 1(1), 17-34.

6 MacIntyre, P. D. (2007). Willingness to communicate in the second language: Understanding the decision to speak as a volitional process. The Modern Language Journal, 91, 564-576. 
using English orally in EFL classes. As Dörnyei mentioned that willingness to communicate in target language has a great impact on learning a foreign language, on the contrary, unwillingness to communicate in target language as a controversial issue hinders learning a foreign language and it is caused by some situational and pedagogical factors $^{7}$. In addition to the affective factors, there are other factors make students be reluctant to participate in oral performance. The way instructor interacts with students and teach them is of importance and should be focused. If students trust the instructor, they can feel more secure. If they feel secure, they can be more spontaneous and less inhibited. For example, Lee and $\mathrm{Ng}$ find out that that teacher strategy is a major determinant of student reticence in classrooms, but it is not the sole factor ${ }^{8}$. Pedagogical factors such as lesson objectives and task type were also found to influence an instructor's classroom-based interaction strategy decision making. Instructor-student relationship is defined as an interaction device an instructor adopts to interact with his/her students in classrooms. It means that instructors have a supporting role in helping the students to motivate students to use language and participate in EFL oral classrooms.

To summarize, there are enough evidence which marks EFL students' speaking reluctance at the university level as one of the problematic issue teachers are facing in EFL oral classes. So far, many studies have been done to investigate the causes of speaking reluctance among EFL university students and to find and suggest strategies in order to overcome such a psychological barrier. But more research should be conducted to find remedial and problem-solving strategies from different perspectives. There has been a lack of reasons identified in prior studies as having influences in fostering students' reticence. Therefore, the present study aims to investigate the causes of reticence among students in EFL speaking classes. The purpose of this study is to explore factors causing reticence in English classrooms in order to fill the gaps in those aspects of reticence which are either ignored in previous research studies or not fully covered in others works and to suggest some problem-solving strategies. Besides, in order to achieve the objectives of this research, we sought to find answers for the questions below:

\footnotetext{
${ }^{7}$ Dörnyei, Z. (2001). Teaching and researching motivation. London: Longman.

${ }^{8}$ Lee, W., \& Ng, S. (2009). Reducing student reticence through teacher interaction strategy. ELT Journal, 64(7), 302-313.
} 
1. What are situational and pedagogical factors affecting the Iranian university EFL students' speaking reluctance?

2. To what extend do the situational and pedagogical factors influence Iranian students' speaking reluctance in university EFL classes?

3. Is there a significant difference between male and female students in terms of situational and pedagogical factors?

\section{LITERATURE REVIEW}

The high level of frustration and anxiety in many language classes indicates that students' individual needs for confidence and support are not met. It is in line with Mantra declared that the classroom that did not convenient to the students made them was not motivated to study in the class ${ }^{9}$. Language instructors' awareness of learners' reticence can help them provide a friendly environment enhancing hopefully more effective participation of EFL learners ${ }^{10}$. As a result, creating a low affective filter is also a condition for learning that is met when there is a good classroom atmosphere and if such psychological barriers are reduced, the students' oral performance is boosted for maximum academic achievement. To encourage more students to engage orally, instructors must first create a relaxing, non-threatening and supportive classroom learning environment ${ }^{11}$. Inadequate linguistic competence has been one of the major factors inhibiting students' participation. In an investigation on Iranian university students' reluctance to participate in EFL classrooms, Baktash \& Chalak revealed that low English proficiency contributed to the students' reluctance in Iranian EFL classrooms ${ }^{12}$.

9 Mantra, D. I. (2013). Factors affecting EFL students' reluctance in using oral communication. Sripsi. English Education Department Faculty of Letters and Culture. State University of Gorontalo.

${ }^{10}$ Chalak, A., \& Baktash, F. (2015). "An investigation on Iranian university students' reluctance to participate in EFL classrooms," Journal of Scientific Research and Development, pp. $1-7$.

${ }^{11} \mathrm{Liu}, \mathrm{M}$. (2005). Causes of reticence in EFL classrooms: A study of Chinese university students. Indonesian Journal of English Language Teaching, 1(2), 220-236.

12 Chalak, A., \& Baktash, F. (2015). "An investigation on Iranian university students' reluctance to participate in EFL classrooms," Journal of Scientific Research and Development, pp. $1-7$. 


\section{Abdolnoor Khaleghi}

\section{METHODOLOGY}

\section{Participants}

This study carried out with 34 undergraduate EFL students majoring in English language teaching from Hormozgan University. The participants of this research were sophomore Iranian university students from Department of English Language. They were 27 female and 7 male aged between 19 to 23 . The case study took place in the selected speaking and listening course classroom at the faculty of Humanities. There were 5 participants participated in interview.

\section{Instruments}

Two instruments were used in this study. The researcher employed an informal 12- items Likert-scale questionnaire developed by the researcher based on his observation and teaching experience as the data collection instruments. In addition to this, a semi-structured interview was conducted to obtain in-depth data. The researcher analyzed the results through using SPSS 23 and applied both quantitative and qualitative methods to understand and present the results better in EFL classrooms. The overall Cronbach's alpha reliability coefficient of the questionnaire is 0.722 .

\section{Procedures}

Permission for the data collection was granted from the English Department manager and instructor. Because participants' security is initially enhanced by using their native language, the questionnaire was translated into the participants' mother tongue. It examined the situational and pedagogical factors of students' reluctance in an EFL setting. The questionnaire Items were measured using a 5-point Likert scale, ranging from 1 (strongly disagree) to 5 (strongly agree). The data were collected in winter of 2015. First, the respondents were informed about the purpose of the study to make their best contribution and assured that their responses would be confidential. Then, the questionnaire was administered to 29 language learners who learned English as a foreign language at speaking and listening course during class in 2015-2016 fall semester. According to Creswell, case study is strategy of research for digging depth information of event, activity, a process or one or more persons ${ }^{13}$. The participants who participated in the interview consisted of five female students. A semi-structured interview was

${ }^{13}$ Creswell, J. W. (2009). Third Edition Research Design: Quantitative, Qualitative, and Mixed Methods Approaches. USA: SAGE. Teachers. British: Continuum. 
conducted in Persian to avoid the influence of the foreign language proficiency and for better justification. The interviewer asked questions, the respondent answered the questions freely. Interviewees' answers were recorded and some reflective notes were written.

\section{FINDINGS AND DISCUSSION}

All the data collected with this research are analyzed by using SPSS 23 and results are represented in the quantitative and qualitative methods as follows:

\section{Quantitative analysis}

The informal Likert-scale questionnaire used in this study was composed of two sub-constructs which were situational factors and pedagogical factors. The questionnaire had 12 items in total and 7 of them were related to situational factors. This section deals with the results and discussion of the answers to the questions put forward at the beginning of the study individually:

1. What are situational and pedagogical factors affecting the Iranian university EFL students' speaking reluctance?

Several situational factors such as instructor's behavior, semester syllabus/course level, lack of prior preparation, participation opportunity, low exposure to communicative activities/settings, class atmosphere, topic selection and some pedagogical factors such as teaching style, instructor-student relationship, course materials, educational system and Low English proficiency are identified to affect student's speaking reluctance. The frequency and percentage of these factors are shown in table 1.

Table 1. Frequency and percentage of situational and pedagogical factors

\begin{tabular}{|l|c|c|c|}
\hline Situational factors & $\mathrm{N}$ & frequency & percentage \\
\hline Teacher's behavior & 29 & 13 & 44.8 \\
Semester syllabus/ course level & 29 & 16 & 55.1 \\
Lack of prior preparation & 29 & 16 & 55.1 \\
Participation opportunity & 29 & 19 & 65.5 \\
Low exposure to communicative activities/settings & 29 & 13 & 44.8 \\
Class atmosphere & 29 & 19 & 65.5 \\
Topic selection & 29 & 19 & 65.5 \\
Pedagogical factors & & & \\
Teaching style & 29 & 23 & 79.3 \\
Instructor - student relationship & 29 & 27 & 93.1 \\
Course materials & 29 & 21 & 72.4 \\
Educational system & 29 & 20 & 69 \\
Low English proficiency & 29 & 23 & 79.3
\end{tabular}


2. To what extend do the situational and pedagogical factors influence Iranian students' speaking reluctance in university EFL classes?

As table 1 illustrates, the pedagogical factors such as instructor-student relationship, teaching style, Low English proficiency and Course materials were found to indicate the highest frequency and percentage among Iranian university EFL students. According to the table, situational factors such as participation opportunity, class atmosphere and topic selection have the same frequency and percentage at moderate level. It also shows that instructor's behavior and low exposure to communicative activities/settings are the lowest among the students. Definitely, it can be understood that pedagogical factors have more effectiveness on speaking reluctance among Iranian university EFL students.

Table 2. Descriptive Statistics of situational and pedagogical factors

\begin{tabular}{|c|c|c|c|c|c|}
\hline Situational factors & Gender & $\mathrm{N}$ & Mean & Std. Deviation & $\begin{array}{l}\text { Std. Error } \\
\text { Mean }\end{array}$ \\
\hline \multirow[t]{2}{*}{ Instructor's behavior } & Male & 7 & 3.71 & 1.113 & .421 \\
\hline & Female & 22 & 3.00 & 1.480 & .316 \\
\hline \multirow{2}{*}{$\begin{array}{l}\text { Semester syllabus/ course } \\
\text { level }\end{array}$} & Male & 7 & 3.71 & .756 & .286 \\
\hline & Female & 22 & 3.64 & .902 & .192 \\
\hline \multirow[t]{2}{*}{ Lack of prior preparation } & Male & 7 & 3.29 & 1.496 & .565 \\
\hline & Female & 22 & 3.45 & 1.184 & .252 \\
\hline \multirow[t]{2}{*}{ Participation opportunity } & Male & 7 & 3.14 & 1.069 & .404 \\
\hline & Female & 22 & 3.95 & 1.090 & .232 \\
\hline \multirow{2}{*}{$\begin{array}{l}\text { Low exposure to } \\
\text { communicative } \\
\text { activities/settings }\end{array}$} & Male & 7 & 4.00 & 1.000 & .378 \\
\hline & Female & 22 & 3.50 & .964 & .205 \\
\hline \multirow[t]{2}{*}{ Class atmosphere } & Male & 7 & 3.57 & 1.134 & .429 \\
\hline & Female & 22 & 3.64 & .902 & .192 \\
\hline \multirow[t]{2}{*}{ Topic selection } & Male & 7 & 3.29 & 1.380 & .522 \\
\hline & Female & 22 & 3.73 & 1.077 & .230 \\
\hline \multicolumn{6}{|l|}{ Pedagogical factors } \\
\hline \multirow[t]{2}{*}{ Teaching style } & Male & 7 & 4.43 & .787 & .297 \\
\hline & Female & 22 & 4.14 & 1.037 & .221 \\
\hline \multirow{2}{*}{$\begin{array}{l}\text { Instructor - student } \\
\text { relationship }\end{array}$} & Male & 7 & 4.43 & .976 & .369 \\
\hline & Female & 22 & 4.68 & .477 & .102 \\
\hline \multirow[t]{2}{*}{ Course materials } & Male & 7 & 3.71 & .756 & .286 \\
\hline & Female & 22 & 4.05 & .844 & .180 \\
\hline \multirow[t]{2}{*}{ Educational system } & Male & 7 & 4.00 & 1.528 & .577 \\
\hline & Female & 22 & 3.82 & .795 & .169 \\
\hline \multirow[t]{2}{*}{ Low English proficiency } & Male & 7 & 3.14 & 1.574 & .595 \\
\hline & Female & 22 & 4.23 & .612 & .130 \\
\hline
\end{tabular}

The factors of Students' speaking reluctance have been a major focus of this research. One area of research has examined the situational variables such as course 
activities, course level, course organization and teachers' behavior (Andrade \& Williams, 2009). The other area of the research has investigated the pedagogical factors affecting low oral participation among University EFL students. Unwillingness to speak is caused not only by pedagogical factors(such as educational system and Low English proficiency ) but also by the situation they are in, suggesting that situational variables such as course level, prior preparation should be included in the investigation.

3. Is there a significant difference between male and female students in terms of situational and pedagogical factors?

Table 3. Situational factors in terms of genders

\begin{tabular}{lcccc}
\hline $\begin{array}{l}\text { Situational factors } \\
\text { Gender }\end{array}$ & & & & sig \\
& Male & & Mean & \\
& & 7 & 3.53 & .493 \\
& Female & 22 & 3.55 & \\
\hline
\end{tabular}

Table 4. Pedagogical factors in terms of genders

\begin{tabular}{lccc}
\hline Pedagogical factors Gender & N & Mean & sig \\
\hline Male & 7 & 3.94 & .382 \\
Female & 22 & 4.18 & \\
\hline
\end{tabular}

The results presented in table 3 and table 4 reveal that there is not statistically a significant between male and female in terms of situational and pedagogical factors. According to the tables, both genders demonstrated a high level of situational and pedagogical factors. Finally, it is seen that female students have a slightly higher level in terms of pedagogical factor.

\section{Qualitative analysis}

This qualitative component was essential to the study because it allowed a deeper analysis of speaking reluctance. Interviewees' answers were recorded and some reflective notes were written and studied in detail. The results of the interview confirmed and completed the findings obtained from the questionnaire. Five female students participated in the interview selectively because the researcher thought that female students could more effectively express their ideas about the causes of their reticence in university EFL classes and their effectiveness on students' low oral participation. In the interview, questions were asked to explore what situational and pedagogical factors are 


\section{Abdolnoor Khaleghi}

involved in causing students' low participation in EFL classes, to what extent Iranian EFL students are affected by such underlying factors. The results were presented as follows:

1. In most cases, participants answered the questions similarly. First, they were asked whether teacher behavior could have an effect on their reluctance. Most stated that instructor behavior has a determining influence on their oral participation and this factor is very crucial to motivate the students and help them to have self-confidence for speaking the target language (English). During the interview, they were asked whether semester syllable and course level are involved in speaking reluctance. The interview results showed that their reluctance is relatively related to the semester syllabus and course level. More than half of the participant agreed with this case. There is also the lack of prior preparation which might influence students' oral participation. Having prior practice on the subject was taken by all the interviewees as a determining factor in reducing their anxiety and participating actively in EFL oral classes. There is no mention of this factor in literature, however, Probably, it had not been found to be a key factor or maybe quite conversely, being taken as granted by the participants. Apart from the interview data, based on the questionnaire (item 3), $50 \%$ of male participants and $50 \%$ of female participants in this study reported ill-preparedness to be anxiety-provoking, and during interviews female interviewees repeatedly posed it as influencing their reluctance. Lack of opportunity due to crowded class and verbal behavior of the instructor is another factor fostering speaking reluctance among Iranian EFL students. Most of these participants asserted that some students are not willing to speak because they have no opportunity to communicate in target language. Students' opportunity to participate actively in the classroom communication may vary with quantity and quality. In order to provide the students with enough opportunity to talk, some researchers believe that the amount of time allocated to student talk has to be increased and the amount of time for teacher talk has to be reduced ${ }^{14}$. Because students who are not willing to speak are living in a country where English

\footnotetext{
${ }^{14}$ Harmer, J. (2000). How to teach English. Beijing: Foreign Language Teaching and Research Press \& Pearson Education Limited.
} 
language is not an everyday language, they have not much exposure to daily communicative activities and oral English. Basically, one way to provide learners with a more natural input is to put them in communicative setting. In addition, the students feel afraid of using English outside class and they are unenthusiastic to use English inside classroom (Ramirez, 2010). The students are not confident with their English when they speak to their friends. It means that by practicing English as always as possible, they can improve the English speaking ability. Most of the participants stated that the low exposure to communicative settings and activities outside the class increasingly affect their speaking reluctance. They believed that if they had more communicative activities with their classmates and friends outside the class, they would improve their speaking. All the interviewees thought that creating a friendly and supportive class atmosphere make students participate actively and without embarrassment in EFL oral classes. They also agreed that stressful class atmosphere impeded their oral participation. It is in line with what Ozturk \& Hurson pointed out that instructor should create motivational environment or conditions in EFL classrooms ${ }^{15}$. In addition to class atmosphere, the participants are asked whether topic selection could have an effect on their reluctance. One of the ways through which instructors can create intimacy between students is to choose topics relating to learners' personal experiences and backgrounds and students should have knowledge about that. Two of the participants believed that selecting boring and complex topics make them reluctant to speak in class. On the contrary, three of the participants reported that they have problems with the topic selection.

2. Another question was about the effect of teaching style. All the participants reported that instructor should have ability to master the language for teaching the student and to use the appropriate method in teaching process. Sometimes students do not know how to start their oral performance and how to express their ideas and to communicate in target language. The results show that students' reluctance is mostly affected by this factor and they think that they have a problem with their instructor's teaching style. This result is similar to what Liu

15 Ozturk, G \& Hurson, C. (2013). Determination of university student's motivation in EFL classroom. Social and Behavioral Sciences. 7 - 12. 
\& Jackson pointed out: with the adoption of communicative approach in the present English language teaching practice, instructors should clearly spell out the aims of the teaching style and explain course objectives ${ }^{16}$. All the participants told that mutual trust and respect between instructor and student give them the feeling of security and comfort to participate in the classroom. All the participants also declared that bad-tempered or serious instructors placed a negative load of stress on them and inhibited them from expressing themselves freely. Students are always encouraged by their instructors to contribute to the classroom discourse, and their participation is often evaluated according to the amount and quality of their talk ${ }^{17}$.

3. Another factor which might cause reluctance is course materials. Baker (2003) asserted that the textbooks should be suitable to the students' condition and environment. It means that the materials that are used by the instructors to teach the students should be familiar with their lives and instructors should give the easiest way to make the students understood the subjects or materials in English. Because if the subjects always were explained by English, the students would be familiar with those materials in English language and it will give positive affect to students in using English in the oral classes.

4. Three of the participants said that they are reluctant to speak English in class because some materials are inappropriate and not related to the subjects which reinforce their oral performance. The participants reported that non-standard educational system from the beginning to the advanced levels made them not learn the language skills practically and finally they could not participate in speaking courses. One of the participants explained it as follows:

"English language courses start up at the sixth grade in Iranian Educational system. While these courses is taught at the first grade in most countries around the world because children have the ability to learn language better in their childhood. Consequently, considering the critical period and delay in organizing English language

\footnotetext{
${ }^{16} \mathrm{Liu}, \mathrm{M} .$, \& Jackson, J. (2009). Reticence in Chinese EFL students at varied proficiency levels. TESL Canada Journal, 26(2), 65-81.

17 Warayet, A. (2011). Participation as a complex phenomenon in the EFL classroom (Doctoral dissertation).
} 
courses, university students are not able to participate in oral communication in academic EFL setting."

The results show that low English proficiency is the most significant factor influencing reluctance. All the participants definitely accepted that their lack of knowledge of grammar and vocabulary interfere with the development of oral proficiency in the English language. Similarly, Savaşçi in a study on the reasons of speaking reluctance among Turkish university students found out that low proficiency is an effective factor in speaking reluctance among EFL students ${ }^{18}$.

\section{CONCLUSION}

The significance of this study was to focus on the underlying factors of speaking reluctance among Iranian university EFL student which is regarded as the problematic issue encountered by teachers in EFL oral classes. As a result, an action research was carried out in one of EFL settings. The findings of the study were highly informative because the interview complemented and supported the questionnaire data. The results of the study indicated that several situational and pedagogical factors increasingly affected students' reticence in speaking courses. One significant finding was that instructor - student relationship, teaching style and low English proficiency as the pedagogical factors found to be the highest factors contributing to students' reluctance. In addition to this, another important point was that pedagogical factors have more negative affect on students' oral participation and hinder their oral performance.

To summarize, this study just investigated the situational and pedagogical factors fostering the low oral participation among Iranian university EFL students. Consequently, further research is needed to examine this challenging issue from different perspectives and to find effective strategies to surmount such a serious problem. The following suggestions may help language instructors and students to obviate this matter:

- Organizing a structurally standard educational system from the beginning levels to the advanced levels.

- Employing competent and highly academic qualified instructors.

18 Savaşçi, M. (2013). Why are some students reluctant to use L2 in EFL speaking classes? An action research at tertiary level. Social and Behavioral sciences, 116. 2682-2686. 
- Motivating students by more communicative activities and their exposure to communicative settings.

- Providing supportive atmospheres for University EFL students.

\section{BIBIIOGRAPHY}

Chalak, A., \& Baktash, F. (2015). “An investigation on Iranian university students' reluctance to participate in EFL classrooms," Journal of Scientific Research and Development, pp. 1-7.

Chalak, A., \& Baktash, F. (2015). "An investigation on Iranian university students' reluctance to participate in EFL classrooms," Journal of Scientific Research and Development, pp. 1-7.

Creswell, J. W. (2009). Third Edition Research Design: Quantitative, Qualitative, and Mixed Methods Approaches. USA: SAGE. Teachers. British: Continuum.

Dörnyei, Z. (2001). Teaching and researching motivation. London: Longman.

Ellis, R. (2005). Principles of Instructed Language Learning. Volume 7, Asian EFL Journal. 209-224.

Hamouda, A. (2013). An exploration of causes of Saudi students' reluctance to participate in the English language classroom. International Journal of English Language Education, 1(1), 17-34.

Harmer, J. (2000). How to teach English. Beijing: Foreign Language Teaching and Research Press \& Pearson Education Limited.

Lee, W., \& Ng, S. (2009). Reducing student reticence through teacher interaction strategy. ELT Journal, 64(7), 302-313.

Liu, M. (2005). Causes of reticence in EFL classrooms: A study of Chinese university students. Indonesian Journal of English Language Teaching, 1(2), 220-236.

Liu, M., \& Jackson, J. (2009). Reticence in Chinese EFL students at varied proficiency levels. TESL Canada Journal, 26(2), 65-81.

MacIntyre, P. D. (2007). Willingness to communicate in the second language: Understanding the decision to speak as a volitional process. The Modern Language Journal, 91, 564-576.

Mantra, D. I. (2013). Factors affecting EFL students' reluctance in using oral communication. Sripsi. English Education Department Faculty of Letters and Culture. State University of Gorontalo. 
Investigation Of Situational - Pedagogical Factors Affecting Speaking Reluctance Among University EFL Students

DOI: $10.30575 / 2017 /$ IJLRES-2018050802

Ozturk, G \& Hurson, C. (2013). Determination of university student's motivation in EFL classroom. Social and Behavioral Sciences. 7 - 12.

Savaşçi, M. (2013). Why are some students reluctant to use L2 in EFL speaking classes? An action research at tertiary level. Social and Behavioral sciences, 116. 2682-2686.

Schmitt. R. (2010). An introduction to applied linguistics. Hodder Education, An Hachette UK Company.

Tsou, W. (2005). Improving speaking skills through instruction in oral classroom participation. Foreign Language Annals, 38(1), 46-55.

Warayet, A. (2011). Participation as a complex phenomenon in the EFL classroom (Doctoral dissertation).

Zhang, X, \& Head, K. (2010). Dealing with learner reticence in the speaking class. ELT Journal, 64(1), 1-9. 